\title{
FAKTOR-FAKTOR YANG BERHUBUNGAN DENGAN PARTISIPASI PRIA DALAM KELUARGA BERENCANA DI KECAMATAN RUMBAI PESISIR TAHUN 2012
}

\author{
YESSI HARNANI* \\ *Dosen Prodi IKM Stikes Hangtuah Pekanbaru
}

\begin{abstract}
The man participation in family planning (FP) mean to take part in this program inspite of founding good sexual behavior for themselves and their wife. This research explore several factors which related to man participation in FP program on Rumbai Pesisir Sub district, Municipality of Pekanbaru in the year of 2012.Research design is case control study, with case is the man not participate in FP program while as control is the man whom taking part on the FP in the year of 2012. Result the man with acces difficulty to family planning program 10 times risk not to participate compared with the counterpart/control (CI 95\% : OR $=5,3-17,9)$, men not supported by social and cultural aspect for family planning program 4 times risk not to participate (CI 95\% : OR=2,4 - 7,9), men with negative opinion to family palnning program 4 times risk not to participate(CI 95\%: $O R=1,3-7,0)$, while the man from low income family 2 times risk not to participate (CI 95\% : OR = 1,2 - 3,5) compared with their counterparts respectively. Conclusion: Multivariate analysis revealed that independent variable related to man participation, the family planning program, social and cultural aspect, opinión to family planning program and family income. Wife age is the only Independence variabel related counter directionally. Parity, education level and knowladge to family planning program are three variables not related to men participation, meanwhile family planning service quality is the confounding variable to service acces variable and social and cultural variable.

Suggestion : increase quality and acces of family planning services including site of service, concellor, cost and spesific family planning promotion for mankind. Family planning and health service program is distributed to all area of Rumbai Pesisir subsdistric and to increase the support of public figure and all stake holder for Family planning program.
\end{abstract}

Key Word : Access to family planning service, social culture,attitudes, income, male participation in family planning

PENDAHULUAN

Partisipasi pria dalam

Keluarga Berencana (KB)adalah tanggung jawab pria dalam kesertaan ber-KB, serta berperilaku seksual yang sehat dan aman bagi dirinya, pasangan dan keluarganya.
$2 \begin{aligned} & \text { Partisipasi } \\ & \text { ek }\end{aligned}$ KB
maupun baik dalam
pemeliharaan Kesehatan Ibu dan

Anak berpengaruh positif dalam mempercepat penurunan angka kelahiran total (TFR), penurunan Angka Kematian Ibu (AKI), dan 
penurunan Angka Kematian Bayi Angka Kematian Ibu (AKI) di Indonesia merupakan yang tertinggi di Asia Tenggara atau keempat di wilayah Asia Pasifik, yaitu mencapai 228 orang per 100.000 kelahiran hidup (SDKI, 2007). Target Millenium Development Goal's (MDGs) tahun 2015 adalah 102/100.000 kelahiran hidup (BKKBN, 2000).Untuk itu Pengaturan kehamilan dan jarak melahirkan diperlukan untuk mencapai target MDGs tersebut melalui berbagai program pemerintah yang salah satunya adalah gerakan keluarga berencana (KB) nasional (Azwar, A. 2005).

Prinsip pokok dalam mewujudkan keberhasilan program KB adalah peningkatan kualitas di segala bentuk serta kesetaraan dan keadilan gender melalui pemberdayaan perempuan serta peningkatan partisipasi pria dalam program KB (BKKBN, 2000).

Ada beberapa metode alat kontrasepsi yang bisa digunakan bagi pria antara lain kondom, vasektomi atau metode operasi pria (MOP), serta $\mathrm{KB}$ alamiah seperti metode senggama terputus dan metode pantang berkala. (Hartanto, H. 2004).Jika dilihat dari efek samping akibat penggunaan alat kontrasepsi, kontrasepsi pria mempunyai efek samping yang lebih kecil dibandingkan kontrasepsi wanita, mulai dari yang ringan hingga yang berat antara lain: mual, muntahmuntah, pusing, bercak-bercak darah di antara masa haid, infeksi jamur di sekitar kemaluan, kram dan nyeri saat haid dan pendarahan yang cukup serius. Dengan demikian keikutsertaan pria dalam ber- KB sangat diperlukan (BKKBN, 2005).

Ada beberapa faktor yang membuat pria enggan untuk ber-KB di antaranya adalah rendahnya
(AKB), (BKKBN, 2002).

pengetahuan dan pemahaman tentang hak-hak reproduksi, keterbatasan alat kontrasepsi pria, faktor lingkungan yaitu sosial, budaya, masyarakat dan keluarga/istri, keterbatasan informasi dan aksesabilitas terhadap pelayanan KB pria, adanya rumor tentang vasektomi serta penggunaan kondom untuk hal yang bersifat negatif. Banyaknya pilihan alat kontrasepsi bagi wanita dibanding pria membuat seolah-olah $\mathrm{KB}$ adalah urusan wanita (Endang, 2002). Pernyataan ini sama dengan penelitian Sri Madya Bhakti (2008) bahwa pengetahuan mempengaruhi seseorang untuk mengambil keputusan dalam penggunaan kontrasepsi.

Berdasarkan data dari Badan Koordinasi Keluarga Berencana Nasional (BKKBN) pencapaian akseptor KB pria baru di Indonesia pada tahun 2007-2009 sudah mengalami peningkatan yaitu 2,66\%, $3,25 \%$ dan 8,90\%. Sementara di Propinsi Riau pencapaian akseptor KB pria aktif dalam dua tahun terakhir mengalami yaitu $5,57 \%$ pada tahun 2009 dan 5,55\% pada tahun 2010, masih belum mencapai target yang diinginkan, sesuai dengan Program Pembangunan Nasional (propernas) tahun 2000 yaitu sebesar 8\%.(BKKBN, 2010).

Dalam dua tahun terakhir pencapaian akseptor KB pria di Kota Pekanbaru merupakan peringkat kelima yang terendah dari 12 Kabupaten/Kota yang ada di Propinsi Riau.Kota Pekanbaru terdiri dari 12 Kecamatan, dan Kecamatan Rumbai Pesisir merupakan salah satu kecamatan yang cakupan akseptor KB pria nya rendah yaitu 3,15\% dari 6663 orang peserta KB aktif seluruhnya adalah akseptor KB Kondom (Dinkes, 2010). 


\section{METODE}

Penelitian ini merupakan penelitian Analitik Kuantitatif dengan desain penelitian stusy kasus kontrol (Case Control Study). Kasus yaitu pria yang tidak berpartisipasi dalam keluarga berencana dan Kontrol yaitu pria yang berpartisipasi dalam keluarga berencana di Kecamatan Rumbai Pesisir kota Pekanbaru tahun 2012, dengan besar sampel 426 orang yaitu 213 orang kasus dan 213 orang kontrol.Prosedur pengambilan sampel dilakukan secara systematic random sampling.Pengolahan data dilakukan dalam tahap editing, coding, processing, cleaning dan tabulating.Analisis data dilakukan yaitu analisis univariat, analisis bivariate dengan uji chi square dan analisis multivariate dengan multiple logistic regression.
HASIL

\begin{tabular}{|c|c|c|}
\hline \multirow[b]{2}{*}{ Variabel } & \multicolumn{2}{|c|}{ Jumlah } \\
\hline & $\mathbf{N}$ & $\%$ \\
\hline \multicolumn{3}{|l|}{ Akses Pelayanan KB } \\
\hline Tidak Terjangkau & 198 & 46,5 \\
\hline Terjangkau & 228 & 53,5 \\
\hline Total & 426 & 100 \\
\hline \multicolumn{3}{|l|}{ Kualitas Pelayanan KB } \\
\hline Kurang Baik & 218 & 51,2 \\
\hline Baik & 208 & 48,8 \\
\hline Total & 426 & 100 \\
\hline \multicolumn{3}{|l|}{ Sikap } \\
\hline Negatif & 225 & 52,8 \\
\hline Positif & 201 & 47,2 \\
\hline Total & 426 & 100 \\
\hline \multicolumn{3}{|l|}{ Pengetahuan } \\
\hline Rendah & 241 & 56,6 \\
\hline Tinggi & 185 & 43,4 \\
\hline Total & 426 & 100 \\
\hline \multicolumn{3}{|l|}{ Sosial Budaya } \\
\hline Tidak Mendukung & 234 & 54,9 \\
\hline Mendukung & 192 & 45,1 \\
\hline Total & 426 & 100 \\
\hline \multicolumn{3}{|l|}{ Usia Istri } \\
\hline Beresiko (<20 \& >35 thn) & 196 & 46,0 \\
\hline Tidak Beresiko (20-35 thn) & 230 & 54,0 \\
\hline Total & 426 & 100 \\
\hline \multicolumn{3}{|l|}{ Pendidikan } \\
\hline Rendah & 169 & 39,7 \\
\hline Tinggi & 257 & 60,3 \\
\hline Total & 426 & 100 \\
\hline \multicolumn{3}{|l|}{ Pendapatan } \\
\hline Rendah & 238 & 55,9 \\
\hline Tinggi & 188 & 44,1 \\
\hline Total & 426 & 100 \\
\hline \multicolumn{3}{|l|}{ Jumlah anak (Paritas) } \\
\hline Beresiko : Paritas $>3$ & 90 & 21,1 \\
\hline Tdk beresiko : Paritas 1-3 & 336 & 78,9 \\
\hline Total & 426 & 100 \\
\hline
\end{tabular}

Hasil uji univariat diketahui bahwa tidak ada variabel yang homogen (salah satu kategorinya 
mempunyai nilai < 20\%).Variabel beresiko (salah satu kategorinya > 50\%) adalah variabel Kualitas pelayanan KB, Sikap, Pengetahuan, Sosial Budaya, dan Pendapatan.

Tabel 2

Analisis Bivariat

\begin{tabular}{|c|c|c|c|c|c|c|}
\hline & \multicolumn{4}{|c|}{$\begin{array}{c}\text { Partisipasi Pria } \\
\text { Dalam KB }\end{array}$} & \multirow[t]{3}{*}{ Value } & \multirow[t]{3}{*}{$\begin{array}{c}\mathrm{OR} / \\
(\mathrm{CI} 95 \%)\end{array}$} \\
\hline Variabel & \multicolumn{2}{|r|}{ Kasus } & \multicolumn{2}{|c|}{ Kontrol } & & \\
\hline & $\mathbf{N}$ & $\%$ & $\mathbf{N}$ & $\%$ & & \\
\hline \multicolumn{7}{|l|}{ Akses Pelayanan KB } \\
\hline Tidak Terjangkau & 156 & 73,2 & 42 & 19,7 & 0,001 & 11,14 \\
\hline Terjangkau & 57 & 26,8 & 171 & 80,3 & & $(7,08-17,54)$ \\
\hline Total & 213 & 1001 & 213 & 100 & & \\
\hline \multicolumn{7}{|l|}{ Kualitas Pelayan KB } \\
\hline Kurang Baik & 144 & 67,6 & 74 & 34,7 & 0,001 & 3,92 \\
\hline Baik & 69 & 32,4 & 139 & 65,3 & & $(2,62-5,86)$ \\
\hline Total & 213 & 100 & 213 & 100 & & \\
\hline \multicolumn{7}{|l|}{ Sikap } \\
\hline Negatif & 152 & 71,4 & 73 & 34,3 & 0,001 & 4,78 \\
\hline Positif & 61 & 28,6 & 140 & 65,7 & & $(3,17-7,20)$ \\
\hline Total & 213 & 100 & 213 & 100 & & \\
\hline \multicolumn{7}{|l|}{ Pengetahuan } \\
\hline Rendah & 140 & 65,7 & 101 & 47,4 & 0,001 & 2,13 \\
\hline Tinggi & 73 & 34,3 & 112 & 52,6 & & $(1,44-3,14)$ \\
\hline Total & 213 & 100 & 213 & 100 & & \\
\hline \multicolumn{7}{|l|}{ Sosial Budaya } \\
\hline Tidak Mendukung & 168 & 78,9 & 166 & 31 & 0,001 & 8,32 \\
\hline Mendukung & 45 & 21,1 & 147 & 69 & & $(5,36-12,90)$ \\
\hline Total & 213 & 100 & 213 & 100 & & \\
\hline \multicolumn{7}{|l|}{ Usia Istri } \\
\hline Beresiko : $<20$ th, $>35$ th & 81 & 38 & 115 & 54 & 0,001 & 0,52 \\
\hline Tidak beresiko : $20-35$ th & 132 & 62 & 98 & 46 & & $(0,36-0,77)$ \\
\hline Total & 213 & 100 & 213 & 100 & & \\
\hline \multicolumn{7}{|l|}{ Pendidikan } \\
\hline Rendah & 67 & 31,5 & 102 & 47,9 & 0,001 & 0,50 \\
\hline Tinggi & 146 & 68,5 & 111 & 52,1 & & $(0,34-0,74)$ \\
\hline Total & 213 & 100 & 213 & 100 & & \\
\hline \multicolumn{7}{|l|}{ Pendapatan } \\
\hline Rendah & 100 & 46,9 & 100 & 46,9 & 0,001 & 2,079 \\
\hline Tinggi & 113 & 53,1 & 113 & 53,1 & & $(1,41-3,07)$ \\
\hline Total & 213 & 100 & 213 & 100 & & \\
\hline \multicolumn{7}{|l|}{ Paritas } \\
\hline Beresiko : Paritas 0 \&>3 & 32 & 15 & 58 & 27,2 & 0,003 & 0,47 \\
\hline Tdk beresiko : Paritas 1-3 & 181 & 85 & 155 & 72,8 & & $(0,29-0,77)$ \\
\hline $\begin{array}{r}\text { Total } \\
\end{array}$ & 213 & 100 & 213 & 100 & & \\
\hline
\end{tabular}


Berdasarkan analisis bivariat diketahui bahwa bahwa variabel independen yang memiliki hubungan signifikan dengan sub hipotesis terhadap partisipasi pria dalam keluarga berencana adalah Akses Pelayanan KB, Kualitas Pelayanan KB,Sikap. Pengetahuan, Sosial Budaya dan Pendapatan. Variabel independen yang memiliki hubungan signifikan terbalik terhadap partisipasi pria dalam keluarga berencana adalah usia istri, pendidikan dan jumlah anak (paritas).

\section{Analisis Multivariat}

Tabel 3

\section{Permodelan Multivariat Akhir}

\begin{tabular}{lccll}
\hline \multicolumn{1}{c}{ Variabel } & P & OR & \multicolumn{2}{l}{$\begin{array}{l}\text { 95\% CI. } \\
\text { For EXP (B) }\end{array}$} \\
\cline { 3 - 5 } & & & Lower & Upper \\
\hline Akses Pelayanan KB & 0,001 & 9,68 & 5,23 & 17,93 \\
Kualitas Pelyanan KB & $\mathbf{0 , 0 5 9}$ & 0,53 & 0,28 & 1,02 \\
Sikap & 0,001 & 3,98 & 2,26 & 6,98 \\
Pengetahuan & $\mathbf{0 , 6 5 8}$ & 1,13 & 0,65 & 1,97 \\
Sosial Budaya & 0,001 & 4,36 & 2,36 & 8,05 \\
UsiaIstri & 0,001 & 0,20 & 0,10 & 0,38 \\
Pendidikan & $\mathbf{0 , 7 5 6}$ & 1,09 & 0,62 & 1,93 \\
Pendapatan & 0,012 & 2,01 & 1,17 & 3,45 \\
Paritas & $\mathbf{0 , 9 9 6}$ & 1,00 & 0,49 & 2,06 \\
& & & & \\
\hline
\end{tabular}

Dari hasil analisis multivariat didapatkan OR dari variabel akses pelayanan KB adalah 9,68 artinya Pria yang sulit menjangkau akses pelayanan KB lebih beresiko tidak berpartisipasi dalam keluarga berencana 10 kali dibandingkan dengan pria yang mudah menjangkau akses pelayanan KB. Pria dengan sosial budaya yang tidak mendukung lebih beresiko tidak berpartisipasi dalam keluarga berencana 4 kali dibandingkan pria dengan sosial budaya yang mendukung.Pria yang bersikap negatif lebih beresiko tidak berpartisipasi dalam keluarga berencana 4 kali dibandingkan pria yang bersikap positif.Pria dengan pendapatan keluarga yang rendah lebih beresiko tidak berpartisipasi dalam keluarga berencana 2 kali dibandingkan pria dengan pendapatan keluarga yang tinggi.Variabel Kualitas Pelayanan KB adalah variabel confounding terhadap variabel akses pelayanan KB dan sosial budaya.

\section{PEMBAHASAN}

Variabel Independen yang Berhubungan dengan Partisipasi Pria dalam Keluarga Berencana

\section{Akses pelayanan KB}

Hasil penelitian ini menunjukkan bahwa kualitas pelayanan $\mathrm{KB}$ confounding terhadap akses pelayanan KB.Untuk meningkatkan Partisipasi pria dalam KB tidak hanya meningkatkan akses pelayanan KB tetapi juga bisa dengan meningkatkan kualitas pelayanan KB.Kualitas pelayanan KB bisa dilihat dari petugas pelayanan yang diinginkan untuk $\mathrm{KB}$ pria, metode kontrasepsi yang disukai dan bentuk KIE KB yang diinginkan.

Pria yang sulit akses ke pelayanan KB lebih beresiko tidak berpartisispasi dalam keluarga berencana dibandingkan pria yang mudah akses terhadap pelayanan KB.Pada penelitian ini diketahui bahwa pria sulit untuk akses kepelayanan KB disebabkan oleh lokasi tempat pelayanan KB jauh dari tempat tinggal mereka seperti RSUD dan puskesmas.Di wilayah Kecamatan Rumbai Pesisir terdapat dua Puskesmas yang letaknya berdekatan ditengah Kecamatan, sehingga masyarakat yang berada dipinggiran Kecamatan sulit untuk akses ke puskesmas.

Puskesmas merupakan pilihan pertama untuk mendapatkan kondom karena gratis dan jaraknya dekat, 
kedua adalah PLKB (Petugas Lapangan Keluarga Berencana) karena faktor kedekatan dengan petugas dan mendapatkan informasi yang lebih lengkap.Sedangkan toko, warung, apotik merupakan tempat pilihan ketiga untuk memperoleh kondom karena bebas memilih dan tidak ingin diketahui orang.

Keterjangkauan pelayanan KB ini dimaksudkan agar pria dapat memperoleh informasi yang memadai dan pelayananKB yang memuaskan.Adanya kemudahan dan ketersediaan sarana pelayanan berdampak positif terhadap penggunaan suatu alat kontarsepsi. Untuk meningkatkan penerimaan partisipasi pria dalam KBperlu dilakukan Komunikasi Informasi dan Edukasi (KIE) mengenaijenis metode kontrasepsi, tempat pelayanan KB, dan biaya PelayananKB melalui pertemuan kelompok atau paguyuban dengan melibatkanPLKB kecamatan, TOMA, TOGA, dan LSM serta penyebaran liflet tentang KB pria.

Hambatan lainnya timbul karena para pengelola dilapangan belum memiliki pedoman operasional dalampengembangan KB khususnya pria.Untuk itu perlu adanya pedoman operasional dan petunjuk tekhnis untuk pengembangan KB pria.

\section{Sosial Budaya}

Hasil penelitian ini menunjukkan bahwa kualitas pelayanan KB juga confounding terhadap sosial budaya.

Pria yang tidak mandapat dukungan sosial budaya lebih beresiko tidak berpartisipasi dalam keluarga berencana dibandingkan pria yang mendapat dukungan. Kualitas pelayanan KB yang baik dapat dilihat dari peran petugas kesehatan yang selalu berusaha meyakinkan masyarakat bahwa keikutsertaan pria dalam ber KB itu penting dan kualitas pelayanan yang baik dalam proses penyampaian KIE (Komunikasi Informasi dan Edukasi) sangat membantu masyarakat dalam mengambil keputusan untuk ber $\mathrm{KB}$ sehingga peran serta pria dalam keluarga berencana dapat ditingkatkan.

Hambatan pria untuk berpartisipasi dalam keluarga berencanasebagian besar dari keluarga/istri.Bahwasanya menurut pendapat istri bila pria dikontap, tidak perkasa lagi, jika menyeleweng tidak ketahuan, KB itu urusan ibu-ibu.Istri tidak setuju/tidak rela suami ikut KB dengan alasan kasihan karena suami mencari nafkah, merasa khawatir suami nyeleweng, takut adanya efek samping terutama penurunan libido, meskipun ada beberapa di antaranya yang setuju dan tidak apa-apa.

Menurut penjelasan beberapa orang tenaga kesehatan setempatdi Kecamatan Rumbai Pesisir menyatakan bahwa hampir semua TOMAdan suami yang ada di wilayah penelitian ini belum bisamenerima KB pria terutama vasektomi.MOP atau KONTAP pria sebagai salah satudari dua cara KB pria masih menjadi bahan perbincangan danperdebatan yang masih terus berlangsung sedangkan cara KBpria berupa kondom tampaknya tidak masalah.

Untuk itu perlu direkomendasikan peningkatan kualitas pelayanan KB dengan meningkatkan jumlah petugas $\mathrm{KB}$ dan lebih sering mengadakan penyuluhan tentang KB pria.Penyuluhan/KIE dapat dilakukan dengan menggerakkan tokohmasyarakat, tokoh agama dan atau kelompokkelompokprofesional lainnya (LSOM), yaitu dengan menggalang kemitraan dan kebersamaan dengan 
sektor, institusi tempat kerja, organisasi profesi, Toma/Toga, LSOM terkait di semuatingkatan.Oleh karena itu perlu adanya komitmen bersamasecara nasional mengenai KONTAP, sehingga keraguan dariberbagai pihak masyarakat maupun pelaksana dapat teratasidan KONTAP dapat lebih diterima secara luas.Dan adanya ketegasan dari TOGA dan TOMA boleh atau tidaknya MOP.

\section{Sikap}

Pria dengan sikap negatif lebih beresiko tidak berpartisipasi dalam keluarga berencana dibandingkan pria dengan sikap positif.Hasil penelitian ini menunjukkan bahwa pria di Kecamatan Rumbai Pesisir menganggap urusan $\mathrm{KB}$ adalahurusan wanita,hal ini disebabkan selama inikebiasaan masyarakat yang menganggap bahwa masalah KB adalah wilayahperempuan dan pria tidak perlu terlibat selain itu masih kurangnya peran dari tokoh masyarakat yangmenjadi kader KB.Padahal tokoh masyarakat salah satu tokoh yang dijadikanpanutan oleh responden.

$\begin{array}{crr}\text { Untuk } & \text { itu } & \begin{array}{r}\text { perlu } \\ \text { direkomendasikan }\end{array} \\ \text { peningkatan }\end{array}$ pemahaman yang benar akan pengetahuan tentang penggunaan alat kontrasepsi pria dan sikap terhadap KB yang lebih positif. Sikap yang peduli terhadap masalah $\mathrm{KB}$ dan kesehatan reproduksi diyakini akan meningkatkan partisipasi pria dalam KB.Dapat diasumsikan bahwa bersikap baik terhadap partisipasi pria dalam KB berarti mendukung untuk berpartisipasi dalam KB.

Perlu diadakannya media dan sarana penyuluhan khusus untuk kaum pria sehingga mengurangi resistensi kaum pria untuk terlibat dalam penyuluhan tersebut, misalnya pertemuan RT, arisan bapak-bapak dan penyuluhan oleh petugas $\mathrm{KB}$, bidan desa dan dokter serta aparat kelurahan dan kecamatan.

\section{Pendapatan}

Pria dengan pendapatan keluarga yang rendah lebih beresiko untuk tidak berpartisipasi dalam keluarga berencana dibandingkan pria dengan pendapatan keluarga yang tinggi.Hasil penelitian ini menunjukkan bahwa responden tidak mau berKB dengan alasan bahwa biaya pelaksanaan MOP itu mahal dan takut menimbulkan gangguan masalah kesehatan seperti timbul rasa nyeri pasca operasi dan adanya abses pada luka operasi.Sedangkan kontrasepsi kondom yang diperoleh di puskesmas biayanya gratis tetapi kualitas kondomnya tidak bagus, mudah bocor dan kurang nyaman digunakan bila dibandingkan dengan kondom yang dijual dipasaran kualitasnya lebih bagus tetapi harganya cukup mahal.Alasan tersebut dikaitkan dengan penghasilan mereka yang rendah dan mereka menganggap tidak akan mampu menjangkau metode ini.

Seharusnya pembiayaan untuk membeli alat kontrasepsi sudah tidak menjadi masalah lagi, karena dalam program pemerintah pelayanan KB untuk masyarakat sekarang sudah digratiskan, sehingga pembiayaan untuk kontrasepsi tidaklah menjadi masalah sekarang ini.Metode kontrasepsi MOP sebetulnya bisa dikatakan lebih murah, karena metode ini hanya dilakukan sekali selamanya. Sedangkan untuk metode lain, misalnya IUD yang sekali pasang hanya untuk jangka waktu tertentu, yang mana setelah itu harus dilepas dan tentunya dipasang lagi bila masih menginginkan metode kontrasepsi membutuhkan biaya lagi. Inilah yang 
membuktikan bahwa metode lain justru lebih mahal dari pada MOP.

Untuk itu perlu direkomendasikan peningkatan Komunikasi Informasi dan Edukasi (KIE) oleh petugas kesehatan, PLKB, kader kesehatan, lintas sector dan Tokoh masyarakat dalam upaya menyebarkan pemahaman bahwa sebagian besar masalah biaya dalam ber KB sudah ditanggulangi oleh program pemerintah seperti safari KB dan penyediaan kondom gratis.

\section{Usia Istri}

Dalam penelitian ini hubungan antara usia istri dengan partisipasi pria dalam keluarga berencana berbanding terbalik hal ini disebabkan adanya kelemahan dalam wawancara terhadap responden dimana pria tidak tahu pasti berapa usia istrinya. Untuk itu Perlu direkomendasikan dilakukan penelitian lebih lanjut pada responden, tempat dan waktu yang berbeda.

\section{Variabel Independen Yang Tidak Berhubungan Dengan Partisipasi Pria dalam Keluarga Berencana}

\section{Jumlah}

Anak

\section{(Paritas)}

Hasil

$$
\text { penelitian }
$$

ini

menunjukkan bahwa tidak ada hubungan antara jumlah anak (paritas) dengan keikutsertaan pria dalam keluarga berencana.Hal ini kemungkinan disebabkan oleh kelemahan dalam menyusun pertanyaan untuk variabel independen jumlah anak (paritas).Dimana peneliti tidak mengklasifikasikan antara jumlah anak yang hidup saat ini dengan jumlah anak yang pernah dilahirkan (lahir hidup atau lahir mati).

\section{Pendidikan}

Penelitian ini menunjukkan tidak ada hubungan antara tingkat pendidikan dengan partisipasi pria dalam keluarga berencana. Hal ini kemungkinan disebabkan oleh kelemahan dalam menyusun pertanyaan untuk variabel independen pendidikan. Dimana peneliti tidak mengklasifikasikan jenjang pendidikan responden ke kelompok yang lebih spesifik seperti tidak tamat SMP atau Tamat SMP dan seterusnya, sehingga bias informasi tidak dapat dihindari.

\section{Pengetahuan}

Hasil penelitian ini menunjukkan tidak ada hubungan yang signifikan antara pengetahuan pria dengan partisipasi pria dalam keluarga berencana. Hal ini kemungkinan disebabkan oleh kelemahan dalam menyusun pertanyaan untuk variabel independen tertentu dan perbedaan budaya antara tempat penelitian.

\section{KESIMPULAN}

Variabel Independen yang mempunyai hubungan sebab akibat dengan Partisipasi Pria dalam Keluarga Berencana adalah akses pelayanan KB, social budaya, sikap dan pendapatan keluarga. Variabel Independen yang berhubungan Terbalik dengan Partisipasi Pria dalam Keluarga Berencana adalah usia istri.

Variabel independen yang merupakan confounding adalah variabel kualitas pelayanan KB confounding dengan akses pelayanan KB dan sosial budaya terhadap partisipasi pria dalam keluarga berencana.

Variabel yang tidak berhubungan sebab akibat dengan Partisipasi Pria dalam Keluarga Berencanaadalah Paritas, pendidikan, dan pengetahuan. 
SARAN

1) Menempatkan salah satu puskesmas pada wilayah yang jauh dari pusat Kecamatan oleh Dinas Kesehatan bekerjasama dengan lintas sektor.

2) Menyediakan petugas kesehatan pria yang melayani KB pria, baik dalam hal KIE dan pelayanan medis.

3) Mengadakan pelatihan untuk dokter umum tentang metoda kontrasepsi mantap (MOP) oleh Dinas Kesehatan.

4) Melakukan penyuluhan tentang jenis metoda kontrasepsi pria, manfaat, tempat pelayanan $\mathrm{KB}$, dan biaya Pelayanan KB melalui pertemuan kelompok atau paguyuban dengan melibatkan Dinas Kesehatan, Puskesmas, BPPKB, PLKB kecamatan, TOMA, TOGA, dan LSM.

5) Menyediakan pedoman operasional dan petunjuk tekhnis untuk pengembangan KB pria oleh Dinas Kesehatan dan Puskesmas.

\section{DAFTAR PUSTAKA}

Azwar, Azrul.(2005).Kebijakan dan Strategi Nasional Kesehatan Reproduksi

di Indonesia.Dirjen Bina Kesehatan Masyarakat. Jakarta.

Badan Pusat Statistik (BPS). (2007). Survei Demografi dan Kesehatan Indonesia (SDKI) 2007. Jakarta.

Bertrand. (2007). Kerangka Pikir Konseptual Permintaan KB serta Dampak Pada Fertilitas.Dalam : BKKBN. Peningkatan Akses dan Kualitas Pelayanan KB.BKKBN. Bandung.

Bhakti, S.M. (2008).Analisis Faktorfaktor yang Berpengaruh
Terhadap Partisipasi Pria Dalam Keluarga Berencana Di Kecamatan Selo Kabupaten Bayolali, Thesis, Universitas Diponegoro, Semarang.

BKKBN.(1998).Faktor-faktor Sosial Budaya yang Mempengaruhi Pemakaian Kontrasepsi Mantap Wanita (MOW) dan Kontrasepsi Mantap Pria (MOP) di Jawa Barat dan Nusa Tenggara Barat. Kerjasama LDUIPULDU BKKBN. Jakarta.

BKKBN.(2000).Peran Pria melalui Program KB dalam Kesehatan Maternal.Gema Partisipasi Pria. Jakarta.

BKKBN.(2000). Peningkatan Peran Suami Dalam Pelaksanaan KB di Lingkungan Keluarganya, Jakarta.

BKKBN.(2002). Peningkatan Partisipasi Pria dalam KB \& Kesehatan Reproduksi.BKKBN. Jakarta.

BKKBN.(2002). Operasionalisasi Program dan Kegiatan Strategis Peningkatan Partisipasi Pria dalam Keluarga Berencana dan Kesehatan Reproduksi, Jakarta.

BKKBN.(2003). Cukilan Data Program Keluarga Berencana Nasional. Jakarta.

BKKBN.(2005). Peningkatan Partisipasi Pria dalam KB \& $K R$. BKKBN. Jakarta.

BKKBN.(2006). Gema Partisipasi Pria, No. 5/V/2006 Jakarta.

BKKBN.(2010). Hasil Pelaksanaan Sub Sistem Pencatatan dan Pelaporan Pelayanan Kontrasepsi dan Pengendalian Lapangan, BKKBN Propinsi Riau.

BKKBN.(2010). Program Keluarga Berencana Nasional Dalam 
Angka Tahun 2005-2009, Jakarta.

Bruce, J. (1999). Fundamental Elements of the Quality of Care, A Simple Frams Work, Studies ini Family Planning.

Budi, S. S. (2008). Thesis Faktorfaktor yang Berhubungan Dengan Partisipasi Pria Dalam Keluarga Berencana Di Kecamatan Jetis Kabupaten Bantul, Undip, Semarang.

Dinas Kesehatan, (2009). Profil Dinas

Kesehatan Kota Pekanbaru Tahun 2009.Pekanbaru

Djamhoer, dkk.(2005). Bunga Rampai Obstetri dan Ginekologi Sosial. Yayasan Bina Pustaka Sarwono Prawiroharjo. Jakarta.

Endang.(2002). Buku Sumber Keluarga Berencana, Kesehatan Reproduksi, Gender, dan Pembangunan

Kependudukan.BKKBN \& UNFPA. Jakarta.

Hartanto, Hanafi dr, (2004).Keluarga Berencana dan Kontrasepsi, Pustaka Sinar Harapan, Jakarta.

Lapau, Buchari. (2010). Diktat Metodologi Penelitian Kesehatan, Jakarta.

Manuaba.(1998). Ilmu Kebidanan, Penyakit Kandungan, \& Keluarga Berencana untuk Pendidikan Bidan.EGC. Jakarta. Notoatmodjo, Soekidjo. (2005). Promosi Kesehatan, Teori dan Aplikasi. Rineka Cipta, Jakarta. Nursalam. (2003). Konsep \& Penerapan Metodologi Penelitian Ilmu Keperawatan, Salemba Medika : Jakarta.

Purwoko.(2000). Tesis Penerimaan Vasektomi dan Sterilisasi Tuba. Fakultas Kedokteran Undip. Semarang.
STIKes Hang Tuah. (2010). Panduan Karya Ilmiah Magister: Pekanbaru.

Suprihastuti, dkk.(2000). Analisis Data Sekunder SDKI 97 Pengambilan Keputusan Penggunaan Alkon Pria di Indonesia. D.I. Yogyakarta.

Syaifudin Abdul Bari, Prof,dr. (2003). Buku Panduan Praktis Pelayanan Kontrasepsi. Yayasan BinaPustaka Sarwono Prawirohardjo. Jakarta. Tanjung, Afrial.

Biostatistik, Tantara Mesta, Bandung. 2009.

Undang-Undang Republik Indonesia Nomor 10 Tahun 1992 tentang perkembangan kependudukan dan pembangunan keluarga sejahtera.

http://birohukumsiskum.sumut prov.go.id/myadmin/undang/1 0\%20Tahun\% 201992.pdf.

Wijayanti, Titik. (2004). Studi Kualitatif Alasan Akseptor Laki-Laki tidak Memilih MOP sebagai Kontrasepsi Pilihan di desa Timpik kecamatan Susukan kabupaten Semarang. Program Studi D IV Kebidanan Stikes Ngudi Waluyo. Ungaran.

Wijono, D. (1999). Manajemen Mutu Pelayanan Kesehatan. Airlangga University Press. Surabaya.

Wiknjosastro, H. (2005). Ilmu Kebidanan. Yayasan Bina Pustaka Sarwono Prawirohardjo. Jakarta. 